\title{
PENGARUH KOMPETENSI SOSIAL PERAWAT TERHADAP KEPUASAN KERJA PERAWAT
}

\author{
Mooniek Setyowati*, Luky Dwiantoro, Bambang Edi Warsito \\ Program Studi Magister Kepemimpinan dan Manajemen Keperawatan, Departemen Ilmu Keperawatan, \\ Universitas Diponegoro Semarang, Jl. Prof. Soedarto, Tembalang, Kec. Tembalang, Kota Semarang, Jawa \\ Tengah, Indonesia 50275 \\ *mookha.mooniek@gmail.com
}

\begin{abstract}
ABSTRAK
Perawat merupakan sumber daya manusia yang penting dirumah sakit. Kompetensi perawat akan mempengaruhi kualitas pekerjaan. Kompetensi sosial harus dimiliki perawat dalam memberikan asuhan keperawatan. Kompetensi sosial berdampak pada kepuasan kerja perawat.Desain penelitian menggunakan Quasy Experimental dengan pre post test with control group. Jumlah sampel 18 kelompok intervensi dan 18 kelompok kontrol. Penggumpulan data penelitian menggunakan kuesioner komptensi sosial dan kuesioner kepuasan kerja Minesotta. Rerata usia responden kelompok intervensi nilai mean 28,8bulan dan kelompok kontrol adalah 29,2, kelompok intervensi mayoritas memiliki pendidikan Diploma III Keperawatan sebanyak 83,3\% dan kelompok kontrol mayoritas berpendidikan Diploma III Keperawatan sebesar 88,9\%. Nilai rata-rata lama kerja kelompok intervensi adalah 4,22 dan standar deviasi 1,39 dan nilai minimal-maksimal 1-6. Pada kelompok kontrol, nilai rata-rata lama kerja adalah 4. Uji analisis pada kelompok intervensi menggunakan Paired ttestdidapatkan hasil p-value sebesar 0,000, hasil tersebut <alpha sehingga dinyatakan terdapat pengaruh intervensi kompetensi sosial terhadap kepuasan kerja perawat.
\end{abstract}

Kata kunci: kompetensi sosial, kepuasan kerja

\section{THE EFFECT OF NURSING SOCIAL COMPTENCE ON NURSING SATISFACTION}

\begin{abstract}
Nurses are important human resources in hospitals. Nurse competence will affect the quality of work. Social competence must be possessed by nurses in providing nursing care. Social competence has an impact on job satisfaction of nurses. Research design uses Quasy Experimental with pre-post test with control group. The number of samples was 18 intervention groups and 18 control groups. Research data collection using social competency questionnaire and Minesotta job satisfaction questionnaire. The mean age of respondents in the intervention group mean value was 28.8 months and the control group was 29.2, the majority intervention group had a Diploma III Nursing education of $83.3 \%$ and the majority control group had a Diploma III Nursing education of $88.9 \%$. The average length of work of the intervention group was 4.22 and the standard deviation was 1.39 and the minimum-maximum value was 1-6. In the control group, the average value of length of work was 4. Discussion: The analysis test in the intervention group using the Paired t-test obtained a p-value of 0,000, the results were <alpha so that it was stated that there was an influence of social competence interventions on nurse job satisfaction.
\end{abstract}

Keywords: social competence, job satisfaction

\section{PENDAHULUAN}

Rumah sakit tempat pemberi layanan kesehatan yang harus memberikan pelayanan unggul dan paripurna. Peran Rumah Sakit dalam mewujudkan masyarakat sehat, menempati bagian yang sangat penting yaitu: promotif, preventif, kuratif dan rehabilitatif. Selain sarana prasarana, pegawai merupakan faktor penting, perawat merupakan bagian yang tidak terpisahkan di rumah sakit (Karimah, 2017).
Kualitas asuhan keperawatan dipengaruhi oleh berbagai pihak. Kualitas asuhan keperawatan dipengaruhi oleh perawat itu sendiri, pola kerja di rumah sakit, dukungan kebijakan rumah sakit, pengakuan prestasi kerja perawat Marquis, 2010). Dalam memberikan asuhan keperawatan, perawat berinteraksi 24 jam dengan pasien dan keluarga. dengan demikian perawat berperan penting menentukan kualitas mutu layanan di rumah sakit, perawat yang puas dengan pekerjaannya maka akan dapat 
menyelesaikan pekerjaan dengan baik dan membuat pasien atau keluarganya puas (Bustami, 2011). Kepuasan kerja diartikan sebagai kondisi emosional terkait pekerjaannya berupa kepercayaan dan kepuasan, harapan terhadap pekerjaan dan loyalitas bekerja dalam organisasi (Elarabi \& Johari, 2014). Hasil penelitian yang dilakukan Newman dan Taylor menyatakan bahwa terdapat hubungan antara kepuasan kerja dengan prestasi kerja karyawan (Huang, 2014; Sandra \& Sondari, 2017).

Fenomena tentang kepuasan kerja perawatan di dunia masih rendah. Di Kanada dan Amerika Serikat, penelitian dengan jumlah sampel 1.783 perawat yang memiliki masa kerja 15 tahun mendapatkan hasil $23 \%$ tidak puas dan sebanyak $9 \%$ menyatkan sangat tidak puas. Penelitian yang dilakukan di 700 rumah skait dengan 43 ribu perawat di negara Inggris, Scotlandia, Jerman, AS, Kanada mendapatkan hasil $41 \%$ merasa tidak puas dengan perkerjaanya, di Jerman 17 persen menyatakan tidak puas (Aiken, Carke, Sloane, Sochalski, Busse, Clarke, Giovannetti, 2001).

Motivasi dan kepuasan kerja perawat masih menjadi permasalahan di negara berkembang. Penelitian yang dilakukan di Thailand tentang kepemimpinan dan kepuasan kerja perawat didapatkan hasil kepuasan kerja perawat masih rendah yaitu 13,79\% (Fitria, Sawitri, 2017). Di Indonesia, dikarenakan pengahargaan yang diberikan kepada perawat masih rendah seperti gaji dan apresisasi kerja, sehingga menyebabkan renfahnya kepuasan kerja .perawat (Wuryanto, 2010).

Penelitian yang dilakukan di Rumah Sakit di Semarangmenunjukkan bahwa kepuasan kerja perawat yang merasa puas sebesar $52,9 \%$ dan kurang puas sebesar $47,1 \%$. Berdasarkan hasil penelitian tersebut, terdapat perbedaannya sangat kecil antara perawat yang memiliki kepuasan kerja kategori puas dengan yang kurang puas dalam pekerjaannya (Transyah, 2012). Penelitian lain yang dilakukan di RSUD Pasaman Barat menunjukkan tingkat kepuasan kerja perawat ruang rawat rendah (Sandra \& Sondari, 2017).

Ketidakpuasan kerja pada perawat akan menyebabkan perawat meninggalkan pekerjaannya, sering mengeluh, menghindari perkerjaan yang menjadi tanggung jawabnya, komunikasi yang tidak baik didalam lingkungan kerja dan produktivitas kerja semakin menurun sehingga dapat menyebabkan tingginya turn over di rumah sakit. Kepuasan kerja yang dimiliki perawat akan menentukan hasil yang dicapai, baik untuk pengembangan dirinya maupun tempat dimana perawat bekerja. Hasil penelitian hubungan kepuasan kerja dengan kinerja mendapatkan hasil ada hubungan kepuasan kerja dengan kinerja (Artadi, 2015; Hartati, Handayani, \& Sholikhah, 2011).

Terdapat enam karakteristik kompetensi yang mempengaruhi kinerja pegawai, yaitu motifmotif (motives), watak (traits), konsep diri (self concept), pengetahuan (knowledge), keterampilan (skill) dan problem solving. Upaya meningkatkan kualitas kinerja pegawai diantaranya adalah menaikkan kepuasan kerja. Keberhasilan kinerja dan kepuasan kerja akan tercapai jika karyawan memiliki kompetensi yang baik, kompetensi yang rendah pada karyawan akan menghasilkan kinerja yang rendah, kompetensi penting yang wajib ada pada karyawan adalah kompetensi sosial (Fattah, 2017).

Kompetensi sosial diartikan sebagai tindakan untuk mencapai tujuan dengan menggunakan cara yang tepat fdan efektif yang dapat memberikan efek positif pada pegawai. Pegawai dengan kompetensi sosial yang baik memiliki kemampuan untuk lebih simpatik, mudah menolong dan mencintai, dengan kata lain keomptensi sosial merupakan kemampuan berkomunikasi, berinteraksi secara efektif dan efisien (Kompri, 2017).

Kompetensi sosial sangat penting pada bisnis yang menjual jasa pelayanan. Kompetensi sosial meliputi kemampuan sosial (ketepatan dalam memahami orang lain), menajemen kesan( kemampuan menginduksi reaksi yang menguntungkan orang lain), dan adaptasi ekspresi (kemampuan mengekpresikan emosi). Salah satu indikasi mutu pelayanan rumah sakit yaitu tingkat kepuasan (Robbin \&Judge, 2013).

Kompetensi sosial yang baik berdampak pada kepuasan kerja. Dampak positif dari kepuasan kerja tinggi adalah meningkatnya prestasi perawat dan kinerja. Hal ini sesuai dengan penelitian Setiawati tentang pengaruh kompetensi kerja terhadap kinerja, hasil penelitian menunjukkan terdapat hubungan yang signifikan antara kompetensi kerja dengan kinerja, kompetensi kerja meliputi: 
kompetensi profesional, kompetensi sosial, kompetensi pedagogik dan kompetensi kepribadian (setiawati, 2009). Tujuan penelitian ini adalah untuk mengetahui pengaruh kompetensi sosial perawat terhadap kepuasan kerja perawat di Rumah Sakit Islam Sultan Agung Semarang.

\section{METODE}

Penelitian ini termasuk dalam jenis Quasy experimentalpre-post design with control group. Peneliti akan melakukan intervensi berupa pelatihan kompetensi sosial dikelompok intervensi dan tidak melakukan tindakan apapaun di kelompok kontrol. Populasi dalam penelitian ini perawat di Ruang rawat inapRSI Sultan Agung semarang. sampel yaitu sebanyak 36 responden dengan rincian 18 responden kelompok intervensi dan 18 responden kelompok kontrol. Instrumen yang digunakan untuk mengumpulkan data pada penelitian ini adalah kuesioner dan lembar observasi. Kuesioner A berisi data karakteristik respondenusia, jenis kelamin, pendidikan, lama kerja. Kuesioner B berisi observasi kompetensi sosial. Kuesioner C berisi kuesioner kepuasan kerja Minesotta.

Uji validitas dilakukan pada instrumen komptensi sosial. Uji validitas membandingkan nilai $r$ tabel dengan $r$ hitung, dimana instrumen dianggap valid jika nilai $r$ hitung lebih besar dari nilai $r$ table (Potter \& Perry, 2001). Hasil uji validitas 25 pernyataa komptensi. Dari hasil analisis terdapat 3 item dinyatakan tidak valid karena nilai $r$ tabel lebih kecil dari nilai $r$ hitung sehingga diperoleh item yang dinyatakan valid yaitu sebanyak 22 item pertanyaan. Uji reliabilitas adalah indeks yang menunjukkan sejauh mana alat ukur yang digunakan dapat dipercaya untuk digunakan. ${ }^{18}$ Reliabilitas menunjukkan sejauh mana hasil pengukuran relatif konsisten jika dilakukan pengukuran berulang-ulang dari waktu ke waktu. Pada penilitian ini dilakukan uji internal consistency yaitu mengujikan instrumen sekali saja. Jika hasil perhitungan mendekati nilai 1 maka dianggap reliabel. Untuk menentukan reliabilitas terhadap butirbutir pernyataan variabel dilakukan pengujian dengan Cronbach's AlphaHasil uji relibilitas didapatkan hasil nilai Alpha Cronbach 0,967. Berdasarkan hasil uji tersebut, instrumen kompetensi sosial dianggap reliabel karena mendekati nilai 1

Pengumpulan data pada penelitian ini menggunakan bantuan enumerator sebanyak 2 orang, sehingga harus ada persamaan persepsi antara enumerator dan peneliti.Untuk mengetahui kekuatan kesepakatan antara enumerator dengan peneliti maka dilakukan uji interrarter reliabiity.Hasil uji interrarter reliabiity didapatkan hasil: enumerator 1 nilai 0,713 dan enumerator $2=0,624$. Hasil uji berada pada rentang $061-0,80$ berarti kekuatan kesepakatan baik.

Uji Shapiro wilk test dilakukan untuk menguji kenormalan data. Uji ini melihat apakah variabel penelitian itu normal atau tidak karena sampel yang digunakan pada penelitian < 50.Uji yang bivariat yang akan digunakan untuk membandingkan hasil sebelum dilakukan intervensi dan sesudah intervensi menggunakan uji Paired T-Test. Dalam penelitian ini, akan dilakukan uji normalitas, analisis bivariat yang akan digunakan untuk mengetahui pengaruh intervensi setelah dilakukan intervensi dengan menggunakan uji Paired T-Testkarena data berdistribusi normal. Ketika seseorang dipilih untuk ikut serta dalam penelitian, peneliti harus memastikan bahwa hak-hak dari responden terlindungi.Prinsipprinsip etik yang perlu diperhatikan dalam penelitian diantaranya adalah beneficence, human dignity dan justice (Anggita, Febriyanti, Utami, Hakam, 2013). Penelitian ini telah dilakukan uji etik di RSI Sultan Agung Semarang dengan nomer surat keterangan uji etik 53/B/RSI-SA/X/2019.

\section{HASIL}

Hasil penelitian disajikan pada tabel berikut.

Tabel 1.

Usia dan lama kerja responden $(n=36)$

\begin{tabular}{cccccccc}
\hline Variabel & \multicolumn{5}{c}{ Kelompok } & \multirow{2}{*}{$p$-value } \\
\cline { 2 - 8 } & \multicolumn{3}{c}{ Intervensi } & \multicolumn{5}{c}{ Kontrol } & \\
\cline { 2 - 8 } & Mean & Min-max & SD & Mean & Min-max & SD & \\
\hline Usia & 28,8 & $24-33$ & 2,32 & 29,2 & $25-33$ & 2,28 & 0,935 \\
\hline Lama Kerja & 4,22 & $1-6$ & 1,39 & 4,0 & $2-6$ & 1,34 & 0,871 \\
\hline
\end{tabular}


Rerata usia responden kelompok intervensi 28,8 tahun dengan nilai minimal 24 tahun dan maksimal 33 tahun. rerata usia kelompok kontrol adalah 29,2 tahun dan nilai minalmaksimal 25-33 tahun. Rerata lama kerja kelompok intervensi adalah 4,22 tahun dan kelompok kontrol 4,22 tahun. Hasil uji homogenitas variabel usia dan lama kerja dinyatakan homogen.

Tabel 2.

Jenis kelamin dan pendidikan resdenpon $(\mathrm{n}=36)$

\begin{tabular}{|c|c|c|c|c|c|c|}
\hline \multirow[t]{3}{*}{ Variabel } & \multicolumn{4}{|c|}{ Kelompok } & \multirow[t]{3}{*}{ Total } & \multirow[t]{3}{*}{ p-value } \\
\hline & \multicolumn{2}{|c|}{ Intervensi } & \multicolumn{2}{|c|}{ Kontrol } & & \\
\hline & & $\%$ & $f$ & $\%$ & & \\
\hline \multicolumn{7}{|l|}{ Jenis kelamin } \\
\hline Laki-laki & 3 & 16,7 & 2 & 11,1 & \multirow{2}{*}{$36(100 \%)$} & \multirow{2}{*}{0,630} \\
\hline Peremuan & 15 & 83,3 & 16 & 88,9 & & \\
\hline \multicolumn{7}{|l|}{ Pendidikan } \\
\hline D3 & 15 & 83,3 & 16 & 88,9 & \multirow[t]{2}{*}{$36(100 \%)$} & \multirow[t]{2}{*}{0,630} \\
\hline S1 & 3 & 16,7 & 2 & 11,1 & & \\
\hline \multicolumn{4}{|c|}{$\begin{array}{l}\text { Responden kelopok intervensi mayoritas } \\
\text { memiliki kelamin perempuan } 15(83,3 \%) \text { dan } \\
\text { kelompok kontrol mayoritas memiliki jenis } \\
\text { kelamin perempuan } 16(88,9 \%) \text {. Variabel } \\
\text { pendidikan pada kelompok intervensi }\end{array}$} & \multicolumn{3}{|c|}{$\begin{array}{l}\text { Keperawatan sebanyak } 83,3 \% \text { dan kelompok } \\
\text { kontrol mayoritas berpendidikan Diploma III } \\
\text { Keperawatan sebesar 88,9\%. Hasil uji } \\
\text { homogenitas jenis kelamin dan pendidikan } \\
\text { homogen dinyatakan homogen. }\end{array}$} \\
\hline
\end{tabular}

Tabel 3.

Kompetensi sosial kelompok kontrol dan kelompok intervensi (n=36).

\begin{tabular}{|c|c|c|c|c|}
\hline \multirow[t]{3}{*}{ Variabel } & \multicolumn{4}{|c|}{ Kelompok } \\
\hline & \multicolumn{2}{|c|}{ Intervensi } & \multicolumn{2}{|c|}{ Kontrol } \\
\hline & Pre Intervensi & Post Intervensi & Pre Intervensi & Post Intervensi \\
\hline \multicolumn{5}{|c|}{ Kompetensi sosial } \\
\hline Baik & $8(44,4 \%)$ & $15(83,3 \%)$ & $9(50 \%)$ & $9(50 \%)$ \\
\hline Buruk & $10(55,6 \%)$ & $3(16,7 \%)$ & $9(50 \%)$ & $9(50 \%)$ \\
\hline \multicolumn{3}{|c|}{$\begin{array}{l}\text { Kompetensi sosial kelompok intervensi } \\
\text { sebelum dilakukan intervensi mayoritas buruk } \\
\text { yaitu sebesar } 8 \text { orang }(44,4 \%) \text {, setelah } \\
\text { dilakukan intervensi mayoritas memiliki }\end{array}$} & \multicolumn{2}{|c|}{$\begin{array}{l}\text { responden }(83,3 \%) \text {. Kelompok kontrol pada } \\
\text { penilaian pertama mendapatkan hasil } \\
\text { mayoritas memiliki kompetensi sosial baik } \\
\text { sebanyak } 9 \text { responden }(50 \%) \text {, dan penilaian } \\
\text { kedua tidak mengalami perubahan. }\end{array}$} \\
\hline
\end{tabular}

Tabel 4.

Kepuasan kompetensi sosial pre\&post intervensi kelompok intervensi $(\mathrm{n}=18)$

\begin{tabular}{|c|c|c|c|}
\hline \multirow[t]{2}{*}{ Sub variabel } & Pre intervensi & \multicolumn{2}{|c|}{ Post intervensi } \\
\hline & Buruk & Baik & Buruk \\
\hline Pengetahuan sosial & - & $18(100 \%)$ & - \\
\hline Kepercayaan diri & $11(61,1 \%)$ & $12(66,7 \%)$ & $6(33,3 \%)$ \\
\hline $7(38,9 \%)$ & $11(61,1 \%)$ & $14(77,8 \%)$ & $4(22,2 \%)$ \\
\hline Sensitivitas sosial & $11(61,1 \%)$ & $11(61,1 \%)$ & $7(38,9 \%)$ \\
\hline $\begin{array}{l}\text { Pengukuran pre intervensi, sub variabel } \\
\text { pengetahuan sosial } 18 \text { repsonden }(100 \%) \\
\text { kategori baik dan post intervensi semua } \\
\text { responden kategori baik. Sub variabel } \\
\text { kepercayaan diri sebelum dilakukan intervensi } \\
\text { mendapatkan hasil } 7 \text { responden }(38,9 \%) \\
\text { kategori baik dan } 11 \text { responden }(61,1 \%) \\
\text { kategori buruk, pada post intervensi kategori } \\
\text { baik meningkat menjadi } 14 \text { responden }(77,8 \\
\% \text { dan kategori buruk turun menjadi } 6\end{array}$ & $\begin{array}{l}\text { respond } \\
\text { sebelum } \\
\text { sebanya } \\
\text { respond } \\
\text { interven } \\
\text { meningk } \\
\text { variabel } \\
\text { didapatk }\end{array}$ & $\begin{array}{l}(33,3 \%) \\
\text { ilakukan inter } \\
7 \text { responden } \\
(61,1 \%) \text {, } \\
\text { mengalami pe } \\
\text { menjadi } 14 \mathrm{re} \\
\text { ensitivitas sos } \\
\text { hasil kategc } \\
(38,9 \%) \mathrm{ka} \\
(61,1 \%) \text {, sete }\end{array}$ & $\begin{array}{l}\text { variabel empati } \\
\text { si responden baik } \\
3,9 \%) \text { buruk } 11 \\
\text { etelah dilakukan } \\
\text { ahan kategori baik } \\
\text { den }(77,8 \%) \text {. Sub } \\
\text { sbelum intervensi } \\
\text { baik sebanyak } 7 \\
\text { ori buruk dan } 11 \\
\text { intervensi kategori }\end{array}$ \\
\hline
\end{tabular}


baik men ingkat menjadi 11 responden (61,1\%).

Tabel 5.

Kepuasan kompetensi sosial pre\&post intervensi kelompok kontrol $(\mathrm{n}=18)$

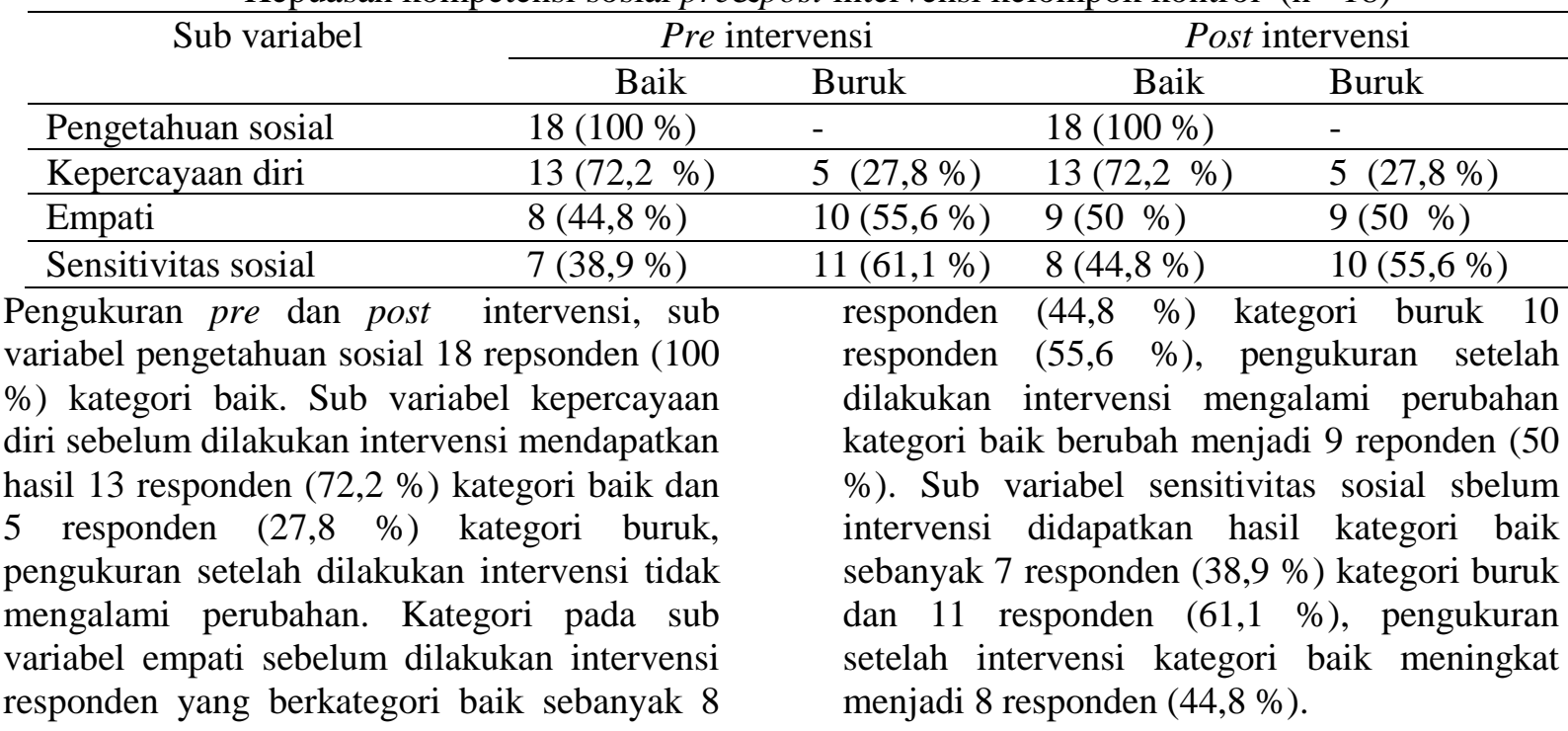

Tabel 6.

Kepuasan kerja kelompok intervensi dan kelompok kontrol $(\mathrm{n}=36)$

\begin{tabular}{|c|c|c|c|c|}
\hline \multirow[t]{3}{*}{ Variabel } & \multicolumn{4}{|c|}{ Kelompok } \\
\hline & \multicolumn{2}{|c|}{ Intervensi } & \multicolumn{2}{|c|}{ Kontrol } \\
\hline & Pre test & Post test & Pre test & Post test \\
\hline \multicolumn{5}{|l|}{ Kepuasan Kerja } \\
\hline Tidak puas & $9(50 \%)$ & $8(44,4 \%)$ & $9(50 \%)$ & $10(55,6 \%)$ \\
\hline Puas & $9(50 \%)$ & $10(55,6 \%)$ & $9(50 \%)$ & $8(44,4 \%)$ \\
\hline \multicolumn{3}{|c|}{$\begin{array}{l}\text { Kepuaan kerja pre test kelompok intervensi } \\
\text { tidak puas berjumlah } 9 \text { responden }(50 \%) \text {, puas } \\
9 \text { responden }(50 \%) \text { dan kepuasan post test } \\
\text { mayoritas puas yaitu } 10 \text { reponden }(55,6 \%) \text {. }\end{array}$} & \multicolumn{2}{|c|}{$\begin{array}{l}\text { pre testtidak puas berjumlah } 9 \text { responden }(50 \\
\%) \text {, puas } 9 \text { responden }(50 \%) \text { dan pada } \\
\text { pengukuran post tess mayoritas tidak puas } \\
\text { sebanyak } 10 \text { responden }(55,6 \%) \text {. }\end{array}$} \\
\hline
\end{tabular}

Tabel 7.

Hasil Analisis Pengaruh Intervensi Terhadap Kepuasan Kerja ( $\mathrm{n}=36)$.

\begin{tabular}{lccccc}
\hline \multirow{2}{*}{ Kepuasan kerja } & \multicolumn{2}{c}{ Kelompok Intervensi } & \multicolumn{2}{c}{ Kelompok kontrol } & \multirow{2}{*}{ p-values } \\
& Mean & SD & Mean & SD & \\
\hline Sebelum intervensi & 57,4 & 4,4 & 57,2 & 4,7 & $0,270^{* *}$ \\
\hline Setelah intervensi & 84,1 & 2,7 & 57,6 & 4,4 & $0.000^{* *}$ \\
\hline$p$-value & \multicolumn{5}{c}{$0,000^{*}$} \\
\hline
\end{tabular}

*Uji paired t-test

** Uji $t$-tes

Hasil uji statistik menggunakan Paired $t$ testpada kelompok intervensididapatkan nilai $p$ value 0,000maka disimpulkan terdapat perbedaan yang signifikan pada pengukuran sebelum intervensi dan setelah intervensi.Hasil analisis pada kelompok kontrol didapatkan hasil 0,476, sehingga dinyatakan tidak ada perbedaan kepuasan kerja pada kelompok kontrol pada penilaian pertama dan kedua. Hasil analisis statistik menggunakan uji independent $t$-test sebelum dilakukan intervensi di kelompok intervensi dan kelompok kontrol didapatkan nilai p-value 0,270 , nilai inilebih besar dibandingkan nilai alpha, dengan demikian dinyatakan dapat disimpulkan bahwa tidak ada perbedaan pada kepuasan kerja pada kelompok intervensi dan kelompok kontrol. Setelah dilakukan intervensi pelatihan didapatkan nilai $p$-value sebesar 0,000, hasil tersebut <alpha sehingga dinyatakan terdapat pengaruh intervensi kompetensi sosial terhadap kepuasan kerja perawat 


\section{PEMBAHASAN}

Hasil analisis pada kompetensi sosial pada kelompok intervensi sebelum dilakukan intervensi mayoritas memiliki kompetensi sosial sedang sebanyak 18 orang $(100 \%)$. Di kelompok kontrol, mayoritas kompetensi sosial adalah sedang sebanyak 17 orang $(94,4 \%)$. Kompetensi sosial kelompok intervensi setelah dilakukan mengalami perubahan yang signifikan yaitu terdapat 17 responden memiliki kompetnsi tinggi $(94,4 \%)$. Sebelum dilakukan intervensi, tidak ada responden yang memiliki kompetensi kategori sedang.Dengan demikian terdapat perubahan yang cukup signifikan setelah dilakukan intervensi pelatihan.Pada kelompok kontrol juga mengalami perubahan tapi hanya 2 responden yang mengalami peningkatan dari kategori sedang ke kategori 3.

Pelatihan dapat meningkatkan kemampuan peserta, baik kemampuan pribadi, profesional dan sosial.Pelatihan merupakan upaya dalam pengembangan sumber daya manusia untuk menjalankan roda organisasi. Dalam pelatihan terjadi transfer ilmu pengetahuan, pengembangan kemampuan berfikir dalam pemecahan masalah. Pelatihan digunakan sebagai persiapan untuk meningkatkan kompetensi pegawai, persiaipan promosi dan peningkatan kinerja (Sandra \& Sondari, 2017). Hasil ini didukung oleh penelitian Febriyanti, Utami dan Hakam (2013), yang menyatakan bahwa pelatihan mempengaruhi kompetensi karyawan.

Pelatihan sangat penting untuk diberikan kepada karyawan untuk meningkatkan kemampuan, kemmapuan karyawan yang meningkat akan mempermudah organisasi dalam mencapai tujuan. Selain itu pelatihan yang diadakan oleh perusahaan akan mempersiiapkan karyawan dalam menghadapai perubahan-perubahan yang terjadi (Aditya, Utami, Ruhana, 2015). Hasil analis kompetensi sosial kelompok intervensi sebelum dan setelah dilakukan intervensi mendapatkan nilai p-value 0,00 , hasil ini lebih kecil dari nilai alpha $(0,005)$ yang berarti ada pengaruh intervensi pelatihan kompetensi sosial terhadap komptensi sosial kelompok intervensi. Hasil penelitian ini sesuai dengan penelitian Aditya, Utami dan Ruhana (2015) yang menyatakan bahwa variabel pelatihan memiliki pengaruh terhadap kompetensi karyawan PLN area Malang (Aditya, Utami, Ruhana, 2015).

Kepuasan kerja merupakan gambaran perasaan berupa senang dan tidak senang terhadap pekerjaan yang dijalani, dan merupakan respon emosional terhadap situasi kerja yang ditentukan oleh hasil yang dicapai, harapan yang terpenehui atau terlampaui. ${ }^{12}$ Kepuasan kerja memiliki kontribusi yang besar dalam upaya mencapai tujuan organisasi, dukungan kepuasan kerja berupa efktivitas organisai, stimulus semangat dalam bekerja dan loyalitas (Rahayuningsih, 2012),

Hasil pengukuran kepuasan kerja menggunakan kuesioner Minessota pada kelompok intervensi sebelum dilakukan penelitian didapatkan hasil mayoritas responden menjawab pertanyaan dengan jawaban tidak puas dan netral.Setelah dilakukan pemeberian intervensi berupa pelatihan kompetensi sosial pada kelompok intervensi, terdapat perubahan jawaban yang signifikan.Setalah dilakukan intervansi dan diukur kembali kepuasan kerja, mayoritas responden menjawab pernyataan pada kuesioner Minessota dengan jawaban puas dan sangat puas.Sebelum dilakukan intervensi tidak ada responden yang memeberikan jawaban sangat puas.

Hasil penelitian ini sesuai dengan teori kepuasan kerja yaitu teori dua faktor.Dalam ini disampaikan bahwa salah satu faktor yang memunculkan kepuasan kerja karyawan adalah faktor pemeliharaan dan faktor motivasi.Faktor motivasi meliputi dorongan untuk berprestasi, mengenalkan kemajuan informasi dan teknologi, memberikan kesempatan berkembang dan bertangung jawab. ${ }^{13}$ pemberian pelatihan merupakan upaya dari organisasi untuk memberikan kesempatan untuk berkembang dengan memberikan pengetahuan dan keterampilan.

Kegiatan pelatihan yang diselenggarakan oleh institusi atau organisasi bertujuan untuk meningkatkan profesionalitas karyawan. Profesionalitas meliputi aspek sikap dan aspek struktural.Aspek sikap terkait dengan pembentukan jiwa profesional.Aspek struktural berhubungan dengan jenis dan bentuk pekerjaan seperti kegiatan pelatihan, kode etik dan pembentukan wadah karyawan. Hasil kegiatan pelatihan diharapkan dapat meningkatkan profesionalitas karyawan. 
Peningkatan profesionalitas karyawan ditandai dengan meningkatnya kompetensi yang berdampak pada kepuasan kerja. Penelitian lain yang mendudkung hasil penelitian ini diantaranya penelitian yang dilakukan oleh Rahayuningsih (2012), yang membuktikan bahwa peningkatan profesionalisme perawat akan meningkatkan kepuasan kerja.

Hasil uji statisitik yang telah dilakukan untuk mengetahui pengaruh pelatihan kompetensi sosial terhadap kepuasan kerja mendapatkan hasil $p$-value $=0,000$. Nilai $p$-value lebih kecil dibandingkan nilai $\alpha$ sehingga dapat disimpulkan bahwa terdapat pengaruh komptensi sosial terhadap kepuasan kerja. Hasil analisis pada penelitian penelitian menunjukkan kompetensi sosial berpengaruh terhadap kepuasan kerja.Hasil penelitian sebelumnya menyatakan adanya pengaruh kompetensi terhadap kepuasan kerja (Sari, 2015). Hal ini menunjukan bahwa jika seoarng perawat ingin meningkatkan kepuasan kerja maka dibutuhkan kompetensi.Kompetensi merupakan kemampuan dan keahlian yang dapat diarahkan untuk mencapai kepuasan kerja maksimal. Hasil penelitian lain menyatakan bahwa terdapat pengaruh yang sigifikan pada varibel kompetensi sosial terhadap kepuasan kerja (Hutagaol, 2015).

\section{SIMPULAN}

Hasil penelitian dapat disimpulkan bahwa terdapat pengaruh kompetensi sosial perawat terhadap kepuasan kerja perawat nilai $p$-value $0,000(<0,05)$.

\section{DAFTAR PUSTAKA}

Aditya, R.Utami,HN. Ruhana, I. (2015). Pengaruh pelatihan terhadap kompetensi dan kinerja karyawan (Studi Pada Karyawan PT. PLN (Persero) Distribusi Jawa Timur Area Malang). JAB. Vol. Oktober 27 (2).

Aiken, L. Carke, S. Sloane, D. Sochalski, J. Busse, R. Clarke, A. Giovannetti, P. et al. (2001). Nurses report on hospital care in five countries. J Health Affairs.2001;(20). 43-45.

Anggita. R. Febriyanti,H. Utami ,N. Hakam.MM. (2013). Pengaruh pelatihan terhadap kompetensi dan kinerja karyawan (Studi Pada PT. Perkebunan Nusantara X (Persero) PG. Lestari
Nganjuk). J Administrasi Bisnis (JAB).2013 April. 1 (2).

Artadi, FF. (2015). Pengaruh kepuasan kerja dan beban kerja terhadap kinerja karyawan pada PT. Merapi Agung Lestari [Skripsi]. Yogyakarta: Universitas Negeri Yogyakarta.

Bustami. (2011). Penjaminan Mutu Pelayanan Kesehatan \& Akseptabilitasnya. Jakarta:Erlangga.

Elarabi, H M. Johari, F. (2014). The determinant factors effecting the job satisfaction and performance in Libyan government hospital. J Asian Social Science. 10 (8).

Fattah, H. (2017). Kepuasan kerja dan kinerja pegawai: Budaya organisasi, perilaku pemimpin dan efikasi diri. Yogyakarta: Elmatera.

Fitria, J. Sawitri, H.S.R. (2017). Pengaruh reward, intensif, pembagian kerja dan pengembangan karir pada kepuasan kerja perawat di RSO Prof. DR. R.Soeharso Surakarta. BENEFIT J Manajemen Dan Bisnis. 1410-4571.

Hartati, S. Handayani, L. Sholikhah. (2011). Hubungan kepuasan kerja dengan prestasi kerja perawat di Instalasi Rawat Inap RSI Klaten. J Kesmas. 2011;5(1):16.

Huang, Su-Ming. (2014). A study of the effect of incentive system on job performancelocus of control as a moderator. JInternational Management Studies. (9).1.

Hutagaol, NH. (2015). Hubungan kompetensi kepribadian dan kompetensi sosial kepala sekolah dengan kepuasan kerja guru smp negeri di kota pematangsiantar. 2015 Des VIII (2).

Karimah, I. (2017). Perbandingan tingkat kepuasan kerja perawat rumah sakit pemerintah dan rumah sakit swasta di Kota Makassar [skripsi]. Makassar: Universitas Islam Negeri Alaudin Makassar. 
Kompri. (2017). Standarisasi kompetensi kepala sekolah, pendidikan teori untuk praktik profesional. Jakarta; Kencana.

Marquis. Huston. (2010). Kepemimpinan dan manajemen keperawatan. Teori dan Aplikasi. Alih bahasa: Widyawati dan Handayani. Jakarta: EGC; 2010

Potter, P. Perry, (2001). A.Fundamental of nursing: Concept, process, and practice. Toronto: Mosby Company.

Rahayuningsih, S. (2012). Analisis pengaruh profesionalisme terhadap komitmen organisasi, kepuasan kerja, prestasi kerja dan keinginan berpindah bagi tenaga profesi perawat. Prociding of conference in business acounting and Mangement 2012. Des 1 (1).

Robbin, S. Judge, T. (2013). Organizational behavior.15th.ed. New Jersey.

Sandra, R. Sondari, D. (2017). Faktor-faktor yang berhubungan dengan kepuasan kerja perawat pelaksana di ruang rawat inap RSUD Solok. J Ilmiah Ilmu-Ilmu Kesehatan ;15. (3).

Sari, FM.. (2015). Pengaruh kompetensi dan lingkungan kerja terhadap kepuasan kerja dan kinerja guru di SD Negeri Kecamatan Gondang Mojokerto. J Ilmu Ekonomi \& Manajemen. 2015;9(2): 137-153.

Setiawati, T. (2009). Pengaruh kompetensi kerja terhadap kinerja dosen (studi kasus di FPTK UPI). J Media pendidikan, gizi, kuliner. 2009 Nov;1(1).

Transyah, C.H. (2012). Faktor-Faktor yang Berhubungan dengan Kepuasan Kerja Perawat Pelaksana di Ruang Rawat Inap RSUP dr.M.Djamil Padang Tahun 2012 [Tesis]. Aliansi UI-Unand Padang.
Wuryanto, E. (2010). Hubungan lingkungan kerja dan karakteristik individu dengan kepuasan kerja perawat di Rumah Sakit Umum Daerah Tugurejo Semarang [Tesis]. Depok: Universitas Indonesia. 